\title{
Antiproliferative effects of fresh water crab hemolymph and meat extract on breast cancer cell line
}

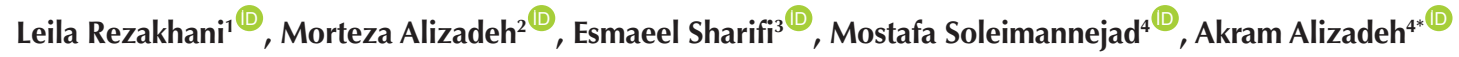 \\ ${ }^{1}$ Department of Tissue Engineering, School of Advanced Technologies, Shahrekord University of Medical Sciences, Shahrekord, \\ Iran \\ ${ }^{2}$ Department of Tissue Engineering, School of Medicine, Shahroud University of Medical Sciences, Shahroud, Iran \\ ${ }^{3}$ Department of Tissue Engineering and Biomaterials, School of Advanced Medical Sciences and Technologies, Hamadan \\ University of Medical Sciences, Hamadan, Iran \\ ${ }^{4}$ Cellular and Molecular Research Center, Basic Health Sciences Institute, Shahrekord University of Medical Sciences, \\ Shahrekord, Iran
}

*Corresponding Author: Akram Alizadeh, Cellular and Molecular Research Center, Basic Health Sciences Institute, Shahrekord University of Medical Sciences, Tel: +989359503052, Email: alizadehbio@gmail.com

\begin{abstract}
Background and aims: Despite the advances in drugs, side effects of chemotherapy drugs continue to exist. Therefore, more attention has been paid to the compounds derived from medicinal herbs and aquatic organisms. This study aimed to investigate the effect of freshwater crab hemolymph and meat extract on breast cancer (BC) cell line (4T1).

Methods: After isolation of freshwater crab hemolymph and meat extract, protein concentration and total antioxidant capacity were analyzed by bicinchoninic acid (BCA) and cupric reducing antioxidant capacity (CUPRAC) methods. The 4T1 cells and bone marrow mesenchymal stem cells (BMSCs) were treated with crab hemolymph $(1,2,10 \mathrm{mg} / \mathrm{mL})$ and meat extract $(0.1,0.2$ and $1 \mathrm{mg} / \mathrm{mL})$, and cell survival was analyzed using 3-(4, 5-dimethylthiazol-2-yl)-2,5-diphenyltetrazolium bromide assay (MTT) at 48 and 72 hours. Nitric oxide (NO) secretion was measured by Griess method. Data were analyzed using one-way analysis of variance (ANOVA).

Results: Protein concentration of $23.25 \mathrm{mg} / \mathrm{mL}$ was shown in crab hemolymph, and $2.3 \mathrm{mg} / \mathrm{mL}$ in meat extract. Total antioxidant capacity was reported as $1.036 \mu \mathrm{M} / \mathrm{mL}$ and $1.104 \mu \mathrm{M} / \mathrm{mL}$ in crab hemolymph and meat extract, respectively. Cell survival in the 4T1 cells was decreased in a dose- and time-dependent manner $(P \leq 0.001)$. NO secretion of $4 \mathrm{~T} 1$ cells was decreased after treatment with different concentrations of crab hemolymph and meat extract at 48 and 72 hours. Cellular growth was observed in BMSCs after treatment with different concentrations of crab hemolymph and meat extract at 48 and 72 hours.

Conclusion: Since crab hemolymph and meat extract have protein and antioxidant activities, they can have anti-cancer effects on 4T1 cells. Keywords: Cell survival, Hemolymph, Meat, Breast neoplasm, Crab
\end{abstract}

Received: 23 March 2020, Accepted: 30 June 2020, ePublished: 30 March 2021

\section{Introduction}

Breast cancer $(\mathrm{BC})$ is the most common type of cancer among women (1). The average age of $\mathrm{BC}$ in Iran is estimated to be between 40-49 years (2). Different chemotherapeutic drugs cause extensive damage to the DNA that destroys normal cells, including gastrointestinal, bone marrow, and hair follicles. Chemotherapy side effects include digestive disorders, reduced count of white blood cells, and hair loss. Drug resistance, as a significant obstacle, reduces the therapeutic effects of chemotherapy agents and avoids the beneficial effects of chemotherapy. Consequently, enhancing therapeutic indices by rising therapeutic effects and reducing toxicity to normal cells is a key issue in cancer treatment (3). Natural products have been a significant medicinal source since ancient times. Medicine utilizes a wide range of natural products, as shown by fact. Approximately, 60\% of approved cancer therapy medicines are of natural origin. Sources of the herbal derivatives are vincristine, etoposide, irinotecan, Taxsan, camptothecin, and resveratrol (46). The chemical and biological diversity of the aquatic organisms is immense; therefore, it is a great source for the discovery of new anticancer drugs (7). The development in compounds identification of aquatic as a therapeutic agent is still in its infancy due to the shortage of traditional medical history compared to the terrestrial habitats. Over the past few decades, considerable efforts have been made by pharmaceutical companies and academic institutions to isolate and identify marine derivatives and new natural products (8). Quantitative and qualitative distribution of carotenoids in freshwater crab meat (Potamon potamon) and shellfish (Charybdis cruciata) from Indian waters was investigated. zeaxanthin and astaxanthin existed in in meat and shell of marine (9). In one Indian tribe, a study was

(C) 2021 The Author(s); Published by Shahrekord University of Medical Sciences. This is an open-access article distributed under the terms of the Creative Commons Attribution License (http://creativecommons.org/licenses/by/4.0), which permits unrestricted use, distribution, and reproduction in any medium, provided the original work is properly cited. 
conducted on the use of several animals and their products in traditional medicine. Crab was one of the animals used as ashes in the treatment of lung diseases, like cough and asthma (10). Crab meat extract as an ingredient in drugs used to treat otorrhea and infection of the ear was in Siddha medicine (11). The crab Scylla serrata has antibacterial, diuretic, and laxative effects and is considered a cardiac stimulus (11). The effect of tachyplesin (acid extracts of horseshoe crab hemocytes) on hepatocarcinoma cells was investigated in a study in China. Tachyplesin inhibited the proliferation of hepatocarcinoma cells, altered enzyme and antigenic rates, regulated tumor suppressor gene expression and differentiation-associated oncogene, and decreased a-FP levels (a-FP is an oncofetal antigen and is a significant tumor-specific marker for hepatocarcinoma detection) (12). We reported the anticancer effects of crab shell on $\mathrm{BC}$ and prostate cancer cell lines in our previous studies. It has been proven that the crab shell contains antioxidants, chitosan, and selenium (13-15). Apoptosis was increased by increasing the dose and time in two cell lines of MCF7 and LNcap, and cell survival decreased (13-15). The aim of this study was to investigate antiproliferative effects of freshwater crab hemolymph and meat extract on BC cell line.

\section{Materials and Methods}

\section{The Species and Place of the Freshwater Crabs}

The freshwater crabs used in this study were from the family of potamidae and the genus potamon and persicum species. All crabs were male, and they were hunted from the Jajrood River in Tehran, Iran in summer 2018 (Figure $1)$.

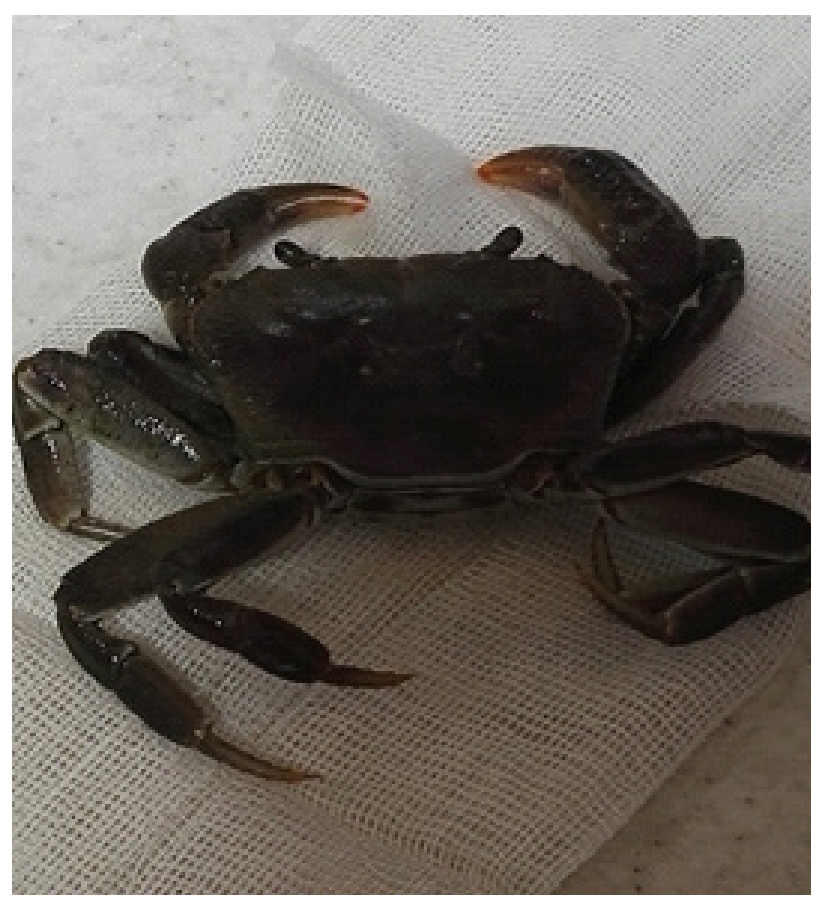

Figure 1. The crab samples used in the present study.

\section{Preparation of crab hemolymph}

After injection of ketamine anesthetic at a dose of $20 \mathrm{mg} /$ $\mathrm{kg}$ to the leg muscle of the crabs (16), the crab body surface was disinfected with $70 \%$ alcohol. After alcohol drying, the feet were separated, hemolymph was originated from this part, and the hemolymph in the sterile container was collected. With centrifuge at $3000 \mathrm{rpm}$ for 20 minutes, the serum was separated and then passed through a filter with a diameter of 0.22 micron. Samples were stored at $-70^{\circ} \mathrm{C}$. All extraction steps were performed on ice.

\section{Preparation of Crab Meat Extract}

After phlebotomy of the crabs, the muscles were removed and transferred to the falcon. The samples were immersed in $2 \%$ potassium chloride for 20 minutes, and then centrifuged for 40 minutes at $3200 \mathrm{rpm}$. Supernatant was filtered with 0.22 -micron filter.

\section{Determination of total antioxidant capacity in crab hemolymph and meat extract by cupric reducing antioxidant capacity method}

In order to determine the total antioxidant capacity in this study, the cupric reducing antioxidant capacity (CUPRAC) method and a kit prepared by Kiazist Company of Iran were used. In this experiment, the cupric was reduced to cuppro in the presence of antioxidants, which produced color in the presence of chromogen. The advantage of this method is the measurement of antioxidants with thiol that are not detected in methods such as iron-based ferric reducing antioxidant power (FRAP) assay. The amount of absorption is directly related to the antioxidant. In this method, standard solution (Trolox) was prepared at 6 different concentrations. The working solution was also prepared according to the kit protocol. To each well from a 96-well plate, $30 \mu \mathrm{L}$ of standards and specimens were added, and then $150 \mu \mathrm{L}$ of working solution was added to them. The plate was incubated at room temperature for 60 minutes. Finally, the absorbance was read at 450 nm wavelength via an ELISA reader (Stat Fax 2100, USA) (17).

Determination of protein concentration in crab hemolymph and meat extract by bicinchoninic acid Assay

Bicinchoninic acid (BCA) assay was used to measure protein concentration. In this method, protein values were determined from the standard curve derived from certain protein concentrations. Preparation and dilution of standards (6 different concentrations of 0 to $1000 \mu \mathrm{g} /$ $\mathrm{mL}$ of bovine serum albumin protein) were according to the protocols. To each microtube, $10 \mu \mathrm{L}$ of the samples (crab hemolymph and meat extract) and standard were added, followed by adding $10 \mu \mathrm{L}$ of working solution. After complete microtube vortex, they were exposed to a temperature of $55^{\circ} \mathrm{C}$ for 25 minutes. After cooling the 
microtubes at room temperature, absorbance was read using a nano drop device (NanoDrop 2000, USA) at 560 nm (Kiazist Company, Iran) (18). After obtaining the amount of protein in $\mu \mathrm{g} / \mu \mathrm{L}$ BCA, three concentrations from both samples were prepared. Based on several pilot tests performed, $1,2,10 \mathrm{mg} / \mathrm{mL}$ concentrations of crab hemolymph and $0.1,0.2$, and $1 \mathrm{mg} / \mathrm{mL}$ concentrations of crab meat extract were prepared.

\section{Cell Line and Cell Culture}

In this study, BC cell line (4T1) was purchased from the cell bank of Pasture Institute in Iran. The cell culture consisted of RPMI 1640 (Sigma), 10\% fetal bovine serum (FBS) (Gibco), and 1\% antibiotic Penicillin/Streptomycin (Sigma) after de-freezing was put in an incubator at $37^{\circ} \mathrm{C}$ and $5 \% \mathrm{CO} 2$. Bone marrow mesenchymal stem cells (BMSCs) were isolated from the femur bone of adult Wistar rats aged 6 to 8 weeks and were cultured in a DMEM medium (Sigma) containing 10\% FBS and $1 \%$ antibiotics. Characterization of stem cells has been performed in previous studies (19).

\section{MTT Assay}

To perform MTT assay (3-(4, 5-dimethylthiazol-2-yl)2,5-diphenyltetrazolium bromide), $10 \times 10^{3}$ cells from the 4T1 and BMSCs were seeded separately in 96-well plates, and then $200 \mu \mathrm{L}$ of the medium was added. Plates were incubated at $37^{\circ} \mathrm{C}$ and $5 \% \mathrm{CO}_{2}$ for 24 hours. Different concentrations of crab hemolymph $(1,2,10 \mathrm{mg} / \mathrm{mL})$ and meat extract $(0.1,0.2$ and $1 \mathrm{mg} / \mathrm{mL})$ were dissolved in 200 $\mu \mathrm{L}$ serum-free medium; then, the solution was added to the respective wells and the plate was incubated again. Control group did not receive treatment. The cells in the control group were treated with serum-free media to ensure that the culture conditions were the same in all groups. MTT test was performed after incubation (48 and 72 hours). First, a solution of $5 \mathrm{mg} / \mathrm{mL}$ of MTT (Sigma) yellow powder was prepared. Then, in a dark environment, $20 \mu \mathrm{L}$ of MTT was added to each well and placed in an incubator at $37^{\circ} \mathrm{C}$ for 3 hours. For the dissolution and extraction of formazan deposits, $100 \mu \mathrm{L}$ of DMSO was added to each well, and after 30 minutes, each well was read by ELISA reader (Stat Fax 2100, USA) at wavelengths of 570 and $630 \mathrm{~nm}$. The percentage of living cells was calculated using the appropriate formula for each concentration (13). Cell viability $(\%)=[$ A570- $630($ sample $) / A($ control $)] \times 100$

\section{Nitric Oxide Assay}

Nitric oxide (NO) is a cell messenger and in cancer increase NO levels (20). The Griess method was used to measure NO. Supernatant 4T1 cells that were exposed at different doses of crab hemolymph and meat extract at 48 and $72 \mathrm{~h}$ intervals were collected. Supernatant was deproteinized by zinc sulfate, and then centrifuged for 12 minutes at $4^{\circ} \mathrm{C}$ and $12000 \mathrm{rpm}$. Next, to $100 \mu \mathrm{L}$ of this supernatant, we added $100 \mu \mathrm{L}$ of Vanadium chloride (Sigma), $50 \mu \mathrm{L}$ sulfanilamide (Sigma), and $50 \mu \mathrm{L}$ NEDD N-(1- Naphthyl) ethylenediamine dihydrochloride (Sigma) and incubated the mixture for 30 minutes at $37^{\circ} \mathrm{C}$ temperature. Sodium nitrate (Sigma) standard solution was prepared at concentrations of $0,6,12,25,50,100$, and $200 \mathrm{mM}$. Standard and samples were read by 540 and $630 \mathrm{~nm}$ by the Eliza Reader (Stat Fax 2100, USA)(13).

\section{Statistical Analysis}

One-way analysis of variance (ANOVA) with post hoc Tukey HSD test was used for data analysis. Data were analyzed by the GraphPad Prism software (version 8). Mean differences were considered significant at $P \leq 0.05$. Each experiment was performed 3 times and the mean of the results was evaluated.

\section{Results}

\section{Total Antioxidant Capacity by CUPRAC Method}

The standard total antioxidant capacity (TAC) was plotted and the antioxidant values of each sample, including the crab hemolymph and the meat extract were $1.036 \mu \mathrm{M} /$ $\mathrm{mL}$ and $1.104 \mu \mathrm{M} / \mathrm{mL}$, respectively (Figure 2 ). The results showed that the TAC in the meat extract was higher than hemolymph.

\section{Protein concentration by BCA method}

The total protein measurements based on different concentrations of standard solutions, absorbance, and standard curve were $23.25 \mathrm{mg} / \mathrm{mL}$ in crab hemolymph and $2.3 \mathrm{mg} / \mathrm{mL}$ in crab meat extract. The above concentrations were calculated according to the standard chart (Figure 3) and the corresponding formula. The results showed that the protein concentration of crab hemolymph was higher than meat extract.

\section{MTT Assay \\ The effect of crab hemolymph on 4 T1 and BMSCs}

Comparison of the viability of the $4 \mathrm{~T} 1$ cell line by MTT assay during 48 and 72 hours showed that the cell survival was reduced by increasing the dose of the crab hemolymph

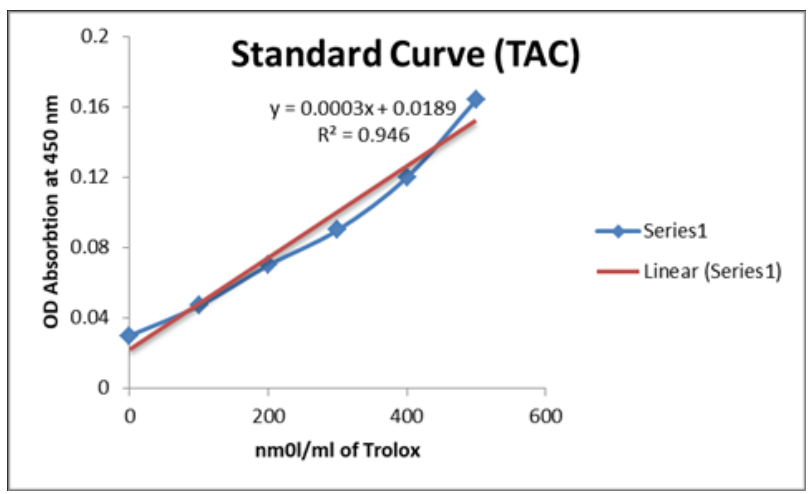

Figure 2. The standard curve for determining the total antioxidant capacity (TAC) by CUPRAC assay. 


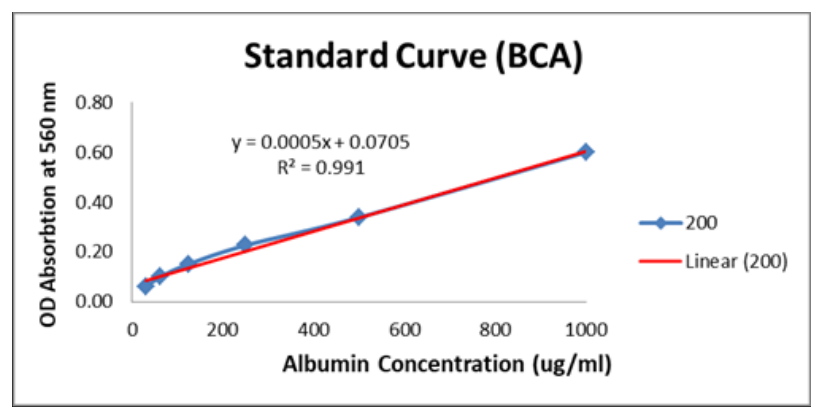

Figure 3. The standard curve for determining the concentration of protein by BCA assay.

compared to the control group. There was a significant difference between the groups $\left(P \leq 0.001^{* * *}, P \leq 0.02^{*}\right)$. The data is shown as mean \pm SD. The BMSCs treated with crab hemolymph were proliferated. $\mathrm{IC}_{50}$ dose of crab hemolymph was $1 \mathrm{mg} / \mathrm{mL}$ at 72 hours (4T1) (Figure $4 \mathrm{a}$ and $b)$.

\section{The effect of meat extract on $4 T 1$ and BMSCs}

After 48 and 72 hours, cell viability with increased dose and time of effect of crab meat extract on $4 \mathrm{~T} 1$ increased compared to control group, and there was a significant difference between the groups $\left(P \leq 0.001^{* * *}, P \leq 0.02^{*}\right)$. The data is shown as mean \pm SD. However, increased growth was seen in BMSCs treated with meat extract. $\mathrm{IC}_{50}$ dose of crab meat extract was $0.1 \mathrm{mg} / \mathrm{mL}$ at 72 hours (4T1) (Figures 5a and 5b).

\section{NO Assay}

NO secretion from 4T1 cells significantly decreased in response to different concentrations of crab hemolymph and meat extract in a dose- and time-dependent manner. There was a significant difference between the groups $\left(P \leq 0.001^{* * *}, P \leq 0.02^{*}\right)$. The data is shown as mean \pm SD (Figures 6 and 7).

As the results show, crab meat extract reduced the amount of NO secretion, which was higher than the groups treated with crab hemolymph.

\section{Discussion}

This study investigated crab hemolymph and meat extract as an anticancer source of marine resources. Natural products are an alternative to chemotherapy drugs without side effects or less complications. Many countries are using crabs in their diet. Antioxidant capacity was reported in

a

a
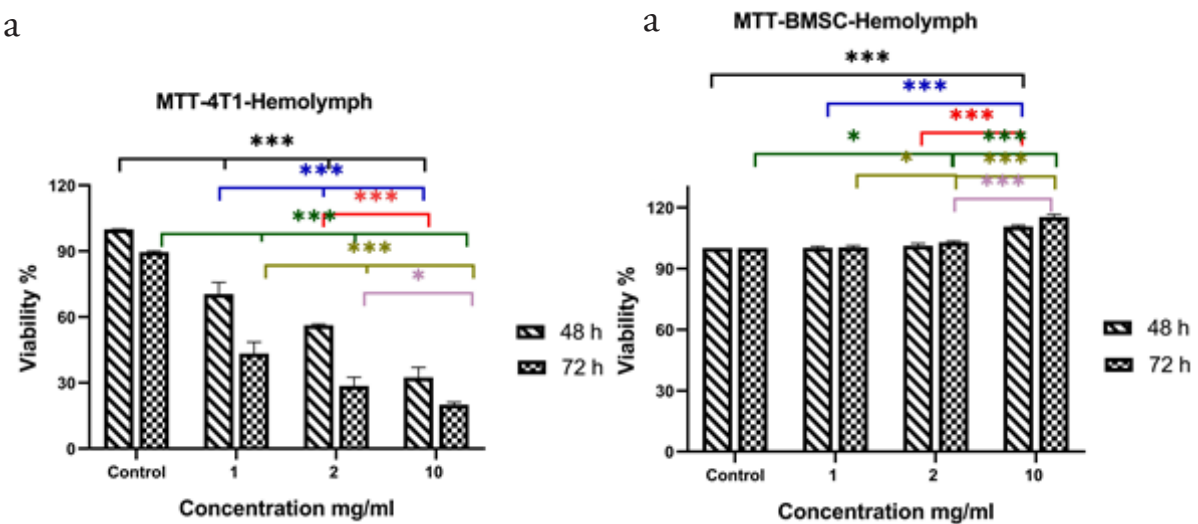

Figure 4. 4T1 (a) and BMSCs (b) Viability (\%) in Different Concentration of Crab Hemolymph (MTT Assay).

Cell viability in the $4 \mathrm{~T} 1$ cancer cell line was decreased in a dose- and time-dependent manner. In the BMSCs, cell growth was increased in a dose- and time-dependent manner. There is significant difference between the groups $\left(P \leq 0.001^{* * *}, P \leq 0.02^{*}\right)$. The data is shown as mean \pm SD.

a

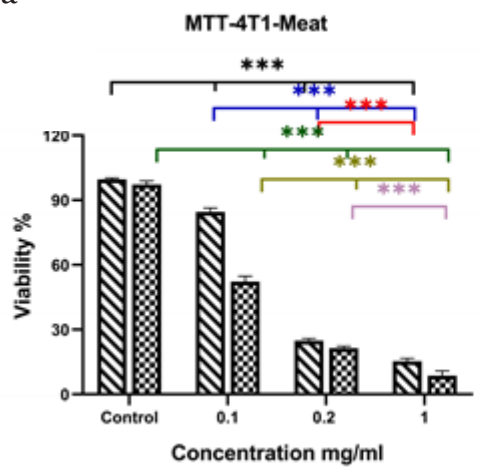

b MTT-BMSC-Meat

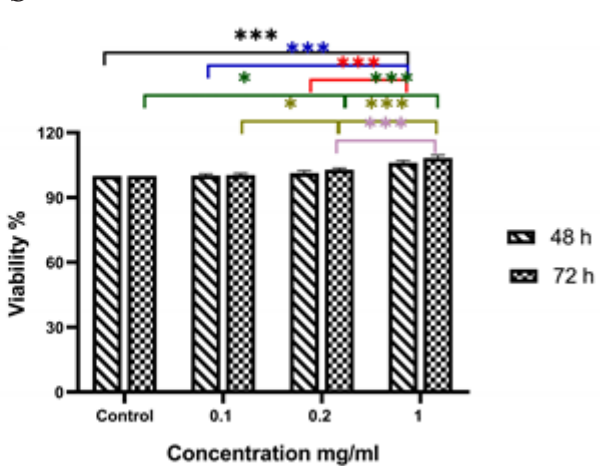

Figure 5. 4T1 Cells (a) and BMSCs (b) Viability (\%) in Different Concentration of Crab Meat Extract by MTT Assay

Cell viability in the 4T1 cancer cell line was decreased in a dose- and time-dependent manner. In the BMSCs, cell growth was increased in a dose- and time-dependent manner. There is significant difference between the groups $\left(P \leq 0.001^{* * *}, P \leq 0.01^{*}\right)$. The data is shown as mean \pm SD. 


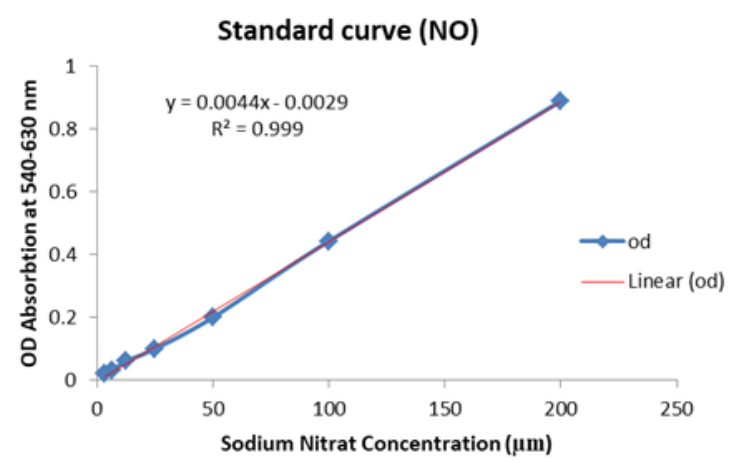

Figure 6. The standard curve for determining the nitric oxide (NO) assay.

crab hemolymph and meat extract. Several studies have measured the antioxidant capacity of different herbal extracts (21). In a study, the effect of various extracts of flower, stem, leaf, and seedlings of Indigo plant on different classes of cancer cells, growth inhibition of these cells with different concentrations of the extracts was reported. Considering the total antioxidant capacity of these extracts and the amounts obtained, the control of cancer cells was directly related to the antioxidant capacity (22). Antioxidants found in various vitamins and minerals have been shown to inhibit cancer. Many studies in this area are in the clinical trial stage $(23,24)$. Since these samples contain antioxidants, and there are also many studies on the presence of antioxidants in seafood (25), they can be considered as complementary therapies in combination with treatments such as chemotherapy, radiotherapy, and surgery in the treatment of cancer (21). The antioxidant capacity calculated from both of the above samples was lower than that of many plant extracts, but the inhibitory effect of cancer cells was significantly higher $(17,21,26)$; this may be due to a specific type of antioxidant that is effective in controlling cancer. This result is similar to the findings of the present report. As witnessed, in the lower concentration of protein in the meat extract, cancer inhibition was found to be higher than that of the hemolymph, which in addition to the role of antioxidant could be due to the presence of certain proteins or mineral elements. The results of a study on the Brachyuran crab hemolymph proteins showed that the effect of nutrition in different regions contributes to the amount of crab hemolymph proteins. Hemolymph proteins have unique compounds in marine invertebrate like crab; they do not contain albumin and immunoglobulin, and their protein constituents change in relation to the physiological and functional state of the animal (27). On the other hand, numerous studies have been carried out on the anticancer effects of proteins. Family Forkhead box proteins, for example, are involved in transcriptional regulation that control a wide range of physiological processes. Disruptions in the function of this protein play a role in promoting cancer. This protein can be used directly or indirectly through biomarkers to treat cancer (28). The expression of genes is also effective in the development of cancer; for example, the expression of a specific isofarm of the ZFX gene has a positive correlation with tumor size (29). Therefore, the protein in the samples may be one of the possible causes of cancer inhibition. This finding is close to the present report's results. In this study, the effect of freshwater crab hemolymph and meat extract on 4T1cell line and BMSCs were evaluated by MTT assay. In studies conducted on crab so far, the type of crab has not been studied in terms of the anticancer effect of hemolymph and meat extracts, and only the anticancer effects of the shell of this type of crab have been investigated in our previous studies $(13,14)$. Different doses of crab hemolymph and meat extract were prepared and applied to $4 \mathrm{~T} 1$ cells in two intervals. $\mathrm{IC}_{50}$ dose of crab hemolymph and meat extract was $1 \mathrm{mg} / \mathrm{mL}$ and $0.1 \mathrm{mg} /$ $\mathrm{mL}$ at 72 hours, respectively. Cellular growth was observed in BMSCs treated with crab hemolymph and meat extract. Therefore, these two samples had no effect on normal cells. Since both samples contain proteins and proteins have anticancer properties, in this study both extracts decreased the survival of cancer cells. On the contrary, the amount of protein concentration from the crab hemolymph was greater than meat extract; but the survival of cancer cells a

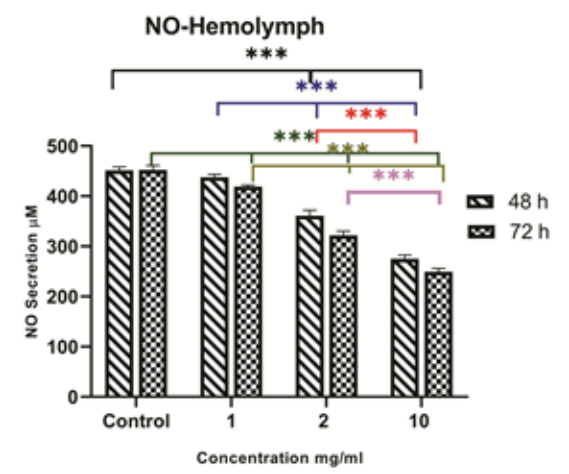

b

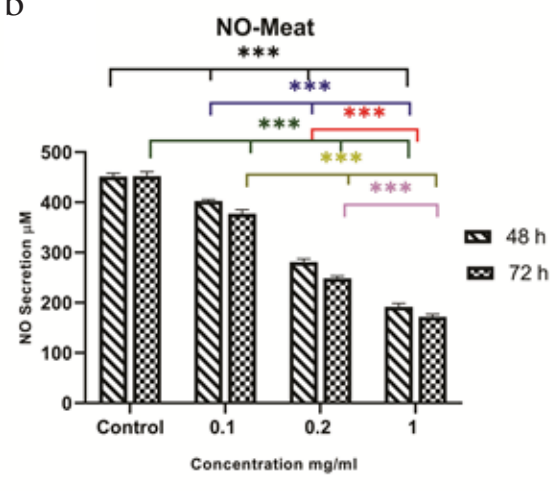

Figure 7. The amount of $\mathrm{NO}(\mu \mathrm{M})$ secretion of $4 \mathrm{~T} 1$ cells after 48 and $72 \mathrm{~h}$ of treatment with different concentrations of crab hemolymph (a) and meat extract (b). NO secretion of $4 \mathrm{~T} 1$ cells decreased in dose and time-dependent manner $\left(P \leq 0.001^{* * *}\right)$. The data is shown as mean \pm SD. 
was significantly reduced by the meat extract, which can be attributed to the amount of TAC explained by these two samples. In one study, the effects of paclitaxel on several levels of $\mathrm{BC}$ were investigated. The up-regulation of FoxO3a by paclitaxel increased levels of protein and caused apoptosis in BC cells (30). Resveratrol is able to inhibit the growth of $\mathrm{BC}$ cells with its antioxidant properties (5). Therefore, the proteins and antioxidants in the crab hemolymph and meat extracts may prevent cancer in $4 \mathrm{~T} 1$ cells. The above studies $(5,30)$ were in line with our studies. NO is considered to be a free radical that causes an increase in oxidative stress (20). A study reported that $\mathrm{NO}$ plays a role in enhancing angiogenesis factors and is capable of producing metastasis in BC (31). In other studies conducted on various cancers such as breast, prostate, and liver treated with different extracts, NO secretion decreased $(13,14,32)$. In our study, both samples were able to reduce $\mathrm{NO}$ secretion in the $\mathrm{BC}$ cell line, but the amount of $\mathrm{NO}$ released in the crab meat extract-treated cells was much higher than that of the crab hemolymph. Our results were in line with other studies in this field.

\section{Conclusion}

The different doses of crab hemolymph and meat extract reported the growth inhibitory effects on BC cells (4T1). TAC was also reported in the above samples. NO secretion in $\mathrm{BC}$ cells decreased by using crab hemolymph and meat extract with dose and time increase. Therefore, crab hemolymph and meat extract with antioxidant ability can inhibit BC cells. It is recommended that future studies monitor crab hemolymph and meat extract from the aspect of molecular and signaling pathways.

Conflict of Interests

The authors declare no conflict of interests.

\section{Ethical Approval}

All animal experiments in this report were done according to the Laboratory Animal Use and Care Committee guideline approved by Animal House of Shahrekord University of Medical Sciences under the approval code of IR.SKUMS.REC.1397.136.

\section{Authors' Contributions}

LR, MA performed the experiments, collected and interpreted the data, drafted and edited the manuscript. ESH and MS participated in data analysis, evaluations and editing the manuscript. AA conceived the idea, participated in study design and supervised the project. All authors read and approved the final manuscript.

\section{Funding/Support}

This study was supported by the Research and Technology Deputy of Shahrekord University of Medical Sciences.

\section{Acknowledgements}

This project was financially supported by Shahrekord University of Medical Sciences (No. 2844). There is no conflict of interests in this study.
References

1. Motamedi M, Hashemzadeh Chaleshtori M, Ghasemi S, Mokarian F. Plasma level of miR-21 and miR-451 in primary and recurrent breast cancer patients. Breast Cancer (Dove Med Press). 2019;11:293-301. doi: 10.2147/bctt.s224333.

2. Hashemian AH, Hajizadeh E, Kazemnejad A, Atri M, Mehdipour P. Penetrance of BRCA1/BRCA2 specific gene mutations in Iranian women with breast cancer. Saudi Med J. 2009;30(1):41-4.

3. Kateb B, Chiu K, Black KL, Yamamoto V, Khalsa B, Ljubimova $J Y$, et al. Nanoplatforms for constructing new approaches to cancer treatment, imaging, and drug delivery: what should be the policy? Neuroimage. 2011;54 Suppl 1:S106-24. doi: 10.1016/j.neuroimage.2010.01.105.

4. Hembruff SL, Laberge ML, Villeneuve DJ, Guo B, Veitch $Z$, Cecchetto $M$, et al. Role of drug transporters and drug accumulation in the temporal acquisition of drug resistance. BMC Cancer. 2008;8:318. doi: 10.1186/1471-2407-8-318.

5. Mirzapur P, Khazaei MR, Moradi MT, Khazaei M. Apoptosis induction in human breast cancer cell lines by synergic effect of raloxifene and resveratrol through increasing proapoptotic genes. Life Sci. 2018;205:45-53. doi: 10.1016/j. Ifs.2018.04.035.

6. Rezakhani L, Mirzapour P, Alizadeh A, Khazaei MR, Alizadeh M, Khazaei M. An overview on plants and natural products with anti-cancer effects. Pathobiol Res. 2018;21(3):163-71. [Persian].

7. Simmons TL, Andrianasolo E, McPhail K, Flatt P, Gerwick WH. Marine natural products as anticancer drugs. Mol Cancer Ther. 2005;4(2):333-42.

8. Amador ML, Jimeno J, Paz-Ares L, Cortes-Funes H, Hidalgo M. Progress in the development and acquisition of anticancer agents from marine sources. Ann Oncol. 2003;14(11):160715. doi: 10.1093/annonc/mdg443.

9. Sachindra NM, Bhaskar N, Mahendrakar NS. Carotenoids in crabs from marine and fresh waters of India. LWT Food Sci Technol. 2005;38(3):221-5. doi: 10.1016/j.Iwt.2004.06.003.

10. Mahawar MM, Jaroli DP. Traditional knowledge on zootherapeutic uses by the Saharia tribe of Rajasthan, India. J Ethnobiol Ethnomed. 2007;3:25. doi: 10.1186/1746-42693-25.

11. Gopal R, Vijayakumaran M, Venkatesan R, Kathiroli S. Marine organisms in Indian medicine and their future prospects. Nat Prod Radiance. 2008;7(2):139-45.

12. Ouyang GL, Li QF, Peng XX, Liu QR, Hong SG. Effects of tachyplesin on proliferation and differentiation of human hepatocellular carcinoma SMMC-7721 cells. World J Gastroenterol. 2002;8(6):1053-8. doi: 10.3748/wjg. v8.i6.1053.

13. Rezakhani L, Khazaei MR, Ghanbari A, Khazaei M. Crab shell extract induces prostate cancer cell line (LNcap) apoptosis and decreases nitric oxide secretion. Cell J. 2017;19(2):231-7. doi: 10.22074/cellj.2016.4879.

14. Rezakhani L, Rashidi Z, Mirzapur P, Khazaei M. Antiproliferatory effects of crab shell extract on breast cancer cell line (MCF7). J Breast Cancer. 2014;17(3):219-25. doi: 10.4048/jbc.2014.17.3.219.

15. Mirzapur P, Rashidi Z, Rezakhani L, Khazaei M. In vitro inhibitory effect of crab shell extract on human umbilical vein endothelial cell. In Vitro Cell Dev Biol Anim. 2015;51(1):3641. doi: 10.1007/s11626-014-9810-x.

16. Quesada RJ, Smith CD, Heard DJ. Evaluation of parenteral drugs for anesthesia in the blue crab (Callinectes sapidus). J Zoo Wildl Med. 2011;42(2):295-9. doi: 10.1638/20090071.1 . 
17. Celik SE, Ozyürek M, Güçlü K, Apak R. Solvent effects on the antioxidant capacity of lipophilic and hydrophilic antioxidants measured by CUPRAC, ABTS/persulphate and FRAP methods. Talanta. 2010;81(4-5):1300-9. doi: 10.1016/j. talanta.2010.02.025.

18. Huang $T$, Long M, Huo B. Competitive binding to cuprous ions of protein and BCA in the bicinchoninic acid protein assay. Open Biomed Eng J. 2010;4:271-8. doi: 10.2174/1874120701004010271.

19. Alizadeh M, Rezakhani L, Soleimannejad M, Sharifi E, Anjomshoa M, Alizadeh A. Evaluation of vacuum washing in the removal of SDS from decellularized bovine pericardium: method and device description. Heliyon. 2019;5(8):e02253. doi: 10.1016/j.heliyon.2019.e02253.

20. Choudhari SK, Chaudhary M, Bagde S, Gadbail AR, Joshi V. Nitric oxide and cancer: a review. World J Surg Oncol. 2013;11:118. doi: 10.1186/1477-7819-11-118.

21. Rugină D, Sconţa Z, Leopold L, Pintea A, Bunea A, Socaciu C. Antioxidant activities of chokeberry extracts and the cytotoxic action of their anthocyanin fraction on HeLa human cervical tumor cells. J Med Food. 2012;15(8):700-6. doi: 10.1089/ jmf.2011.0246.

22. Heo BG, Park YJ, Park YS, Bae JH, Cho JY, Park K, et al. Anticancer and antioxidant effects of extracts from different parts of indigo plant. Ind Crops Prod. 2014;56:9-16. doi: 10.1016/j.indcrop.2014.02.023.

23. Rusciani L, Proietti I, Paradisi A, Rusciani A, Guerriero G, Mammone A, et al. Recombinant interferon alpha-2b and coenzyme Q10 as a postsurgical adjuvant therapy for melanoma: a 3-year trial with recombinant interferon-alpha and 5-year follow-up. Melanoma Res. 2007;17(3):177-83. doi: 10.1097/CMR.0b013e32818867a0.

24. Muecke R, Micke O, Schomburg L, Buentzel J, Glatzel M, Baaske D, et al. Impact of treatment planning target volumen (PTV) size on radiation induced diarrhoea following selenium supplementation in gynecologic radiation oncology--a subgroup analysis of a multicenter, phase III trial. Radiat Oncol. 2013;8:72. doi: 10.1186/1748-717x-8-72.

25. Ngo DH, Wijesekara I, Vo TS, Van Ta Q, Kim SK. Marine foodderived functional ingredients as potential antioxidants in the food industry: an overview. Food Res Int. 2011;44(2):523-9. doi: 10.1016/j.foodres.2010.12.030.

26. Koksal E, Bursal E, Dikici E, Tozoglu F, Gulcin I. Antioxidant activity of Melissa officinalis leaves. J Med Plants Res. 2011;5(2):217-22.

27. Rameshkumar G, Ravichandran S, Kaliyavarathan G, Ajithkumar TT. Comparison of protein content in the haemolymph of brachyuran crabs. Middle East J Sci Res. 2009;4(1):32-5.

28. Myatt SS, Lam EW. The emerging roles of forkhead box (Fox) proteins in cancer. Nat Rev Cancer. 2007;7(11):847-59. doi: 10.1038/nrc2223.

29. Rahmati S, Emadi-Baygi M, Nikpour P, Emadi-Andani E. Expression profile of ZFX isoform3/variant 5 in gastric cancer tissues and its association with tumor size. Iran J Basic Med Sci. 2014;17(10):767-71.

30. Sunters A, Fernández de Mattos S, Stahl M, Brosens JJ, Zoumpoulidou G, Saunders CA, et al. FoxO3a transcriptional regulation of Bim controls apoptosis in paclitaxel-treated breast cancer cell lines. J Biol Chem. 2003;278(50):49795805. doi: 10.1074/jbc.M309523200.

31. Nakamura Y, Yasuoka H, Tsujimoto M, Yoshidome K, Nakahara $M$, Nakao K, et al. Nitric oxide in breast cancer: induction of vascular endothelial growth factor-C and correlation with metastasis and poor prognosis. Clin Cancer Res. 2006;12(4):1201-7. doi: 10.1158/1078-0432.ccr-05-1269.

32. Parizadeh MR, Ghafoori Gharib F, Abbaspour AR, Tavakol Afshar J, Ghayour-Mobarhan M. Effects of aqueous saffron extract on nitric oxide production by two human carcinoma cell lines: hepatocellular carcinoma (HepG2) and laryngeal carcinoma (Hep2). Avicenna J Phytomed. 2011;1(1):43-50. 